\title{
Comparison of bio-agents and botanicals with fungicides against tikka and anthracnose diseases of groundnut (Arachis hypogea
} L.)

MOHAMMAD FAISAL* AND SHASHI TIWARI

Department of Plant Protection, Sam Higginbottom Institute of Agriculture, Technology and Sciences, ALLAHABAD (U.P.) INDIA

\section{ARITCLE INFO}

Received : 04.08 .2014

Revised : 15.01 .2015

Accepted : 30.01 .2015

\section{KEY WORDS :}

Bio-agents, Botanicals, Fungicides, Groundnut, Anthracnose Tikka disease

*Corresponding author:

Email: mfaisal710@gmail.com

\begin{abstract}
Groundnut is an important oilseed crop and contributes about 40 per cent of total oilseed production in India. Due to its nutritional value and oil production, it is very valuable and economical crop but several diseases like tikka, collar rot, rust, peanut bud necrosis and anthracnose take heavy toll every year decrease the yield severely. A field trail was conducted in Kharif season in the month of August, 2012 to test the effect of seed treatment with bioagents, botanicals in comparison to chemical fungicides against tikka disease and anthracnose of groundnut to minimize the disease intensity. The treatments were control (water irrigation), Trichoderma harzianum 1 per cent, Trichoderma viride 1 per cent, Neem seed kernel extract 5 per cent, Pseudomonas flourescens 5 per cent, Bavistin 0.2 per cent, Thiram 0.2 per cent, Neem oil 5 per cent. Seed treatment with Bavistin@0.2 per cent was found superior among all the treatments in managing the tikka leaf spot, whereas, neem oil showed better results next to it. However, anthracnose infection was very little or negligible.
\end{abstract}

How to view point the article : Faisal, Mohammad and Tiwari, Shashi (2015). Comparison of bioagents and botanicals with fungicides against tikka and anthracnose diseases of groundnut (Arachis hypogea L.). Internat. J. Plant Protec., 8(1) : 45-48. 